\title{
Comparison of Clinical Features and Treatment Outcome of Breast Cancers in Young and Elderly Chinese Patients
}

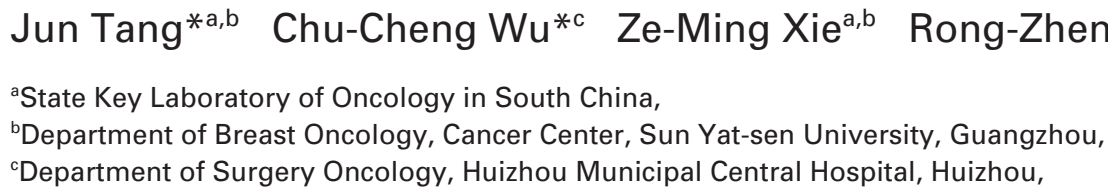 \\ ${ }^{\mathrm{d} D e p a r t m e n t}$ of Pathology, Cancer Center, Sun Yat-sen University, Guangzhou, China
}

\section{Keywords}

Breast cancer - Molecular subtypes - Prognostic features . Very young women . Elderly women

\section{Summary}

Background: This study aimed to investigate the clinicopathological features and prognosis of operable breast cancers in young and elderly Chinese women. Patients and Methods: This study included 209 patients aged $\leq 35$ years and 213 patients aged $\geq 60$ but $<70$ years, who received treatment between January 2000 and December 2004. The clinicopathological features, molecular subtypes, therapeutic strategies, and prognosis were evaluated. Results: Tumor size was of significant difference between the 2 groups ( $p=0.018$, with more T2 and T3 tumors in the young group and more lymph node involvement in young patients with stage T1 tumors ( $p=0.033$ ). There were more triple-negative and less luminal $A$ tumors in the young group ( $p=0.018$ ). $47.1 \%$ of tumors were not detected by mammography in the young group as compared to $5.5 \%$ in the elderly group $(p<0.001)$. More patients received chemotherapy in the young group $(p<0.001)$ and preferred breast-conserving surgery ( $p=0.031)$. The 6-year diseasefree survival (DFS) was 80 and $66 \%$ in the elderly and the young group, respectively ( $p=0.001)$, but no difference was seen in overall survival. Conclusions: Compared with elderly women, young breast cancer patients have different clinicopathological features and molecular subtypes, and poorer DFS. Furthermore, the insidious onset of breast cancer in young women suggests that clinicians should pay more attention to young women with breast abnormalities.

*Jun Tang and Chu-Cheng Wu equally contributed to this article.

\section{Schlüsselwörter}

Mammakarzinom · Molekulare Subtypen · Prognostische Merkmale · Sehr junge Frauen · Ältere Frauen

\section{Zusammenfassung}

Hintergrund: Ziel dieser Studie war es, die klinisch-pathologischen und prognostischen Merkmale des operablen Mammakarzinoms bei jungen und älteren chinesischen Frauen zu untersuchen. Patienten und Methoden: Die Studie umfasste 209 Patienten im Alter von $\leq 35$ Jahren sowie $213 \mathrm{~Pa}$ tienten im Alter von $\geq 60$ aber $<70$ Jahren, welche zwischen Januar 2000 und Dezember 2004 behandelt wurden. Klinisch-pathologische Merkmale, molekulare Subtypen, therapeutische Strategien und Prognose wurden evaluiert. Ergebnisse: Bei der Tumorgröße bestand zwischen den beiden Gruppen ein signifikanter Unterschied ( $p=0,018$ ). In der jungen Patientengruppe traten mehr T2- und T3-Tumoren auf, und junge Patientinnen mit T1-Tumoren zeigten mehr Lymphknotenbeteiligung ( $p=0,033$ ). Desweiteren traten in der jungen Patientengruppe mehr triple-negative Mammakarzinome und weniger Luminal-A-Tumoren auf ( $p=0,018$ ), und $47,1 \%$ der Tumoren wurden nicht im Rahmen einer mammographischen Untersuchung erkannt $(5,5 \%$ in der älteren Patientengruppe) $(p<0,001)$. Eine größere Anzahl junger Patientinnen wurde chemotherapeutisch behandelt $(p<0,001)$ und zog eine brusterhaltende Operation vor $(p=0,031)$. Das erkrankungsfreie Überleben nach 6 Jahren war 80 bzw. 66\% in der älteren bzw. jungen Patientengruppe ( $p=0,001)$. Beim Gesamtüberleben war kein Unterschied zu verzeichnen. Schlussfolgerung: Verglichen mit älteren Frauen zeigen junge Mammakarzinompatientinnen andere klinisch-pathologische Merkmale und molekulare Subtypen sowie ein schlechteres erkrankungsfreies Überleben. Desweiteren erfordert die oft heimtückische Natur von Mammakarzinomen bei jungen Frauen gesteigerte Aufmerksamkeit seitens des behandelnden Arztes bei abnormalen Befunden in dieser Patientengruppe.

\section{KARGER \\ Fax +497614520714 \\ Information@Karger.de}

www.karger.com (c) 2011 S. Karger GmbH, Freiburg

$1661-3791 / 11 / 0066-0435 \$ 38.00 / 0$

Accessible online at:

www.karger.com/brc
Prof. Dr. Ming-Tian Yang

Department of Breast Oncology, Cancer Center

Sun Yat-sen University

651 Dongfeng R E, Guangzhou, China

Tel. +8620 873433-15, Fax-92

yangmt1@hotmail.com 


\section{Introduction}

Breast cancer at a young age is thought to be less well differentiated and to have low hormone receptor expression and more vascular invasion, resulting in a higher proliferation fraction and more aggressive biological behavior [1-3]. However, whether young age is a hallmark of poor prognosis remains controversial [1, 4]. Many studies revealed obvious survival differences between young and elderly breast cancer patients [2,5], but other studies concluded that young age had no impact on [6-8] or even improved the prognosis [4, 9]. Breast cancer is one of the most common cancers in Chinese women, and its incidence is increasing. The proportion of young age-onset breast cancer is very high in China [10], but its clinical features and prognosis are unclear. In order to investigate the clinical and biological features of breast cancer arising in very young Chinese patients and to provide evidence for tailored therapy, we conducted a retrospective study on operable breast cancers in very young and elderly women registered for surgery in our hospital, and investigated clinicopathological factors, molecular subtypes, therapeutic strategies, and outcome.

\section{Patients and Methods}

Between January 2000 and December 2004, 1,885 consecutive operable breast cancer patients were registered for surgery at the Sun Yat-sen University Cancer Center. Patients aged less than 35 years ( $\leq 35$ years) or older than 60 years but less than 70 years $(\geq 60,<70$ years $)$ were selected for the present study, because most patients aged $\geq 70$ years were not given chemotherapy, which may have lead to bias when comparing treatment strategies. Patients were excluded based on the following criteria: ductal carcinoma in situ at first diagnosis, unavailable information for primary tumor, patients with distant metastasis or other malignancies. This study was approved by the Ethics Committee of the Sun Yat-sen University Cancer Center, and all patients provided oral and written informed consent, indicating their awareness of the investigational nature of the study. In total, 209 (11.1\%) 'very young' patients ( $\leq 35$ years) and $213(11.3 \%)$ 'elderly' patients $(\geq 60,<70$ years) were included. Tumor staging was performed according to the American Joint Committee on Cancer (AJCC) pTNM staging system for breast cancer. 4 subtypes were defined according to the standards reported by Carey et al. [11]: Luminal A (estrogen receptor (ER)- or progesterone receptor (PgR)-positive/Her2-negative), Luminal B (ER- or PgR-positive/Her2-positive), Her2 overexpression (ER- and PgR-negative/Her2-positive), and triple-negative (ER- and PgR-negative/Her2negative). Her2 status was evaluated by immunohistochemistry (IHC) and fluorescence in situ hybridization (FISH). A threshold of $3+$ evaluated by IHC was defined as positive, those of $2+$ were further evaluated by FISH. The breast imaging data of these patients were reviewed to collect information with respect to the findings of ultrasonography and mammography. During the study period, breast cancer patients registered to our center were treated consistently according to our treatment guidelines. Modified radical mastectomy was the most common surgical procedure, radical mastectomy was recommended when patients were classified as clinical stage III. Adjuvant chemotherapy was recommended for patients with positive axillary lymph nodes or a tumor $\geq 1 \mathrm{~cm}$ in diameter. The regimen used was primarily anthracycline-containing chemotherapy; 10 patients in the elderly group received 6 cycles of intravenous cyclo- phosphamide, methotrexate and 5-fluorouracil (CMF) for comorbidities. Hormone therapy (tamoxifen at a dose of $20 \mathrm{mg}$ daily for 5 years) was administered to patients who had ER- or PgR-positive tumors. Radiotherapy was recommended for patients who underwent breast-conserving surgery, patients with 4 or more positive lymph nodes, and those with a tumor $\geq 5 \mathrm{~cm}$ in diameter. All data on therapeutic strategies were collected. Follow-up ran from the date of diagnosis to January 2010. Disease-free survival (DFS) was defined as the interval from the date of surgical treatment to the first locoregional (including chest wall, regional lymph nodes, ipsilateral breast) or distant metastasis. Cancer-related death and non-cancer-related death were distinguished during data analysis. The data were analyzed using the SPSS v.16.6 statistical software SPSS Inc., Chicago, IL, USA). Clinical information, imaging findings, pathological features, molecular subtypes, and therapeutic strategies of the 2 groups were analyzed by chi-square test; a two-sided $\mathrm{p}$ value of $<0.05$ was considered statistically significant. Survival rates were calculated by the life-table method. Survival curves were calculated by the Kaplan-Meier method, differences in survival were estimated by the log-rank test. Multivariate analyses were conducted using Cox's proportional hazard regression model.

\section{Results}

We analyzed $209(11.1 \%)$ very young patients ( $\leq 35$ years) and $213(11.3 \%$ ) elderly patients ( $\geq 60,<70$ years). As shown in table 1 , tumor size was of significant difference between the 2 groups $(\mathrm{p}=0.018)$. Less T1 tumors $(30.1$ vs. $38 \%)$ but more $\mathrm{T} 2$ and T3 tumors were observed in the very young group. Pathological stage showed there were more stage II and III tumors in the very young group $(p=0.037)$. The relevance analysis between tumor size and lymph node involvement showed that more young patients with $\mathrm{T} 1$ stage had positive lymph nodes $(\mathrm{p}=0.033)$. Molecular subtypes were also significantly different between the 2 groups $(\mathrm{p}=0.018)$. Less Luminal A tumors were observed in the very young group than in the elderly group (43.1 vs. $51.7 \%$ ), whereas, there were more triple-negative tumors in the very young group ( 27.8 vs. $16.2 \%$ ). Tumors with histological grade 3 were more prevalent in very young patients than in elderly patients (45.0 vs. $32.9 \%$; $\mathrm{p}=0.038)$.

We reviewed the breast imaging data of all patients. 85 patients in the very young group and 110 patients in the elderly group accepted both preoperative breast ultrasonography and mammography (table 2). The tumor detection rate with ultrasonography showed no difference between the 2 groups ( $\mathrm{p}=0.723$ ), whereas the tumor detection rate with mammography was significantly lower in the very young group than in the elderly group $(\mathrm{p}<0.001)$.

As shown in table 3, there were significant differences in surgical methods $(\mathrm{p}=0.031)$, more young patients preferred breast-conserving surgery, and more elderly patients chose mastectomy. More patients received chemotherapy and radiotherapy in the very young group $(\mathrm{p}<0.001, \mathrm{p}=0.027$, respectively).

The median follow-up period was 72 months (range 1-123 months). In the very young patient group, recurrences 


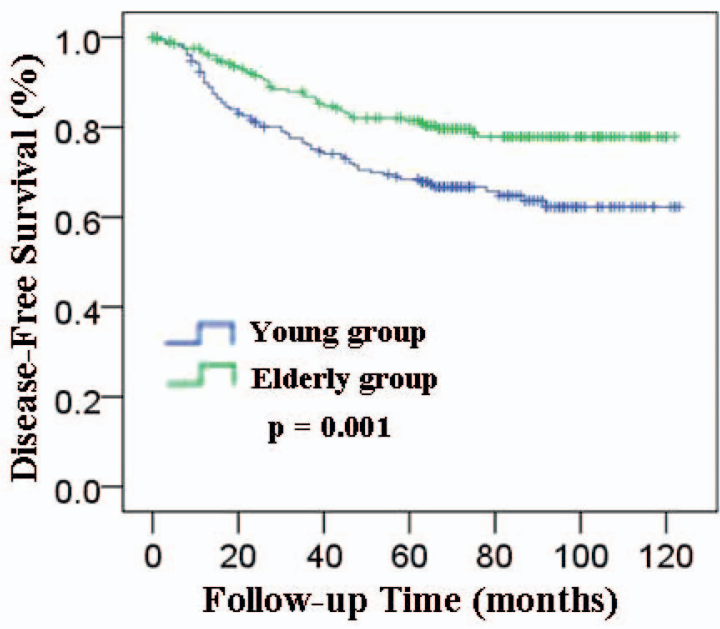

Fig. 1. Kaplan-Meier curves of disease-free survival in the very young group $(\mathrm{n}=209)$ and the elderly group $(\mathrm{n}=213)$.

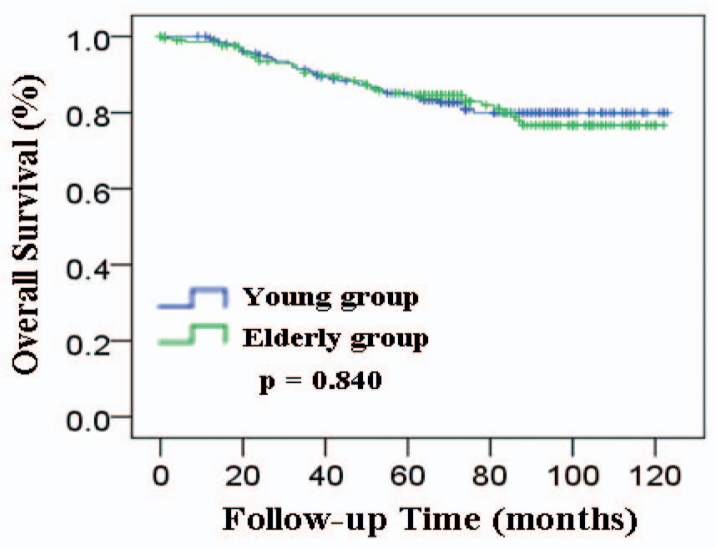

Fig. 2. Kaplan-Meier curves of overall survival in the very young group $(\mathrm{n}=209)$ and the elderly group $(\mathrm{n}=213)$.

occurred in 71 cases, 36 cases died from breast cancer, and no patient died from non-cancer-related causes. In the elderly patient group, recurrences occurred in 41 cases, 38 cases died from breast cancer, and 2 patients died from non-cancer-related causes. Younger patients had a worse DFS, with the 6-year DFS being 66 and $80 \%$ in the very young and the elderly group, respectively ( $p=0.001$ ) (fig. 1 ). After adjustment for tumor size, lymph node status, ER status, PR status, Her2 status, histological grade and chemotherapy in a Cox model, the risk of disease progression for the very young patients was 1.557 times higher than that for the elderly patients (95\% confidence interval $(\mathrm{CI})=1.12-2.38)$ (table 4$)$. A higher risk of disease progression was also found for patients with a positive lymph node status, Her2 overexpression, and histological grade 3 (hazard ratio $(\mathrm{HR})=1.71,95 \% \mathrm{CI}=1.19-2.45$; $\mathrm{HR}=1.71,95 \% \mathrm{CI}=1.19-2.45 ; \mathrm{HR}=1.71,95 \% \mathrm{CI}=1.19$ 2.45 , respectively) (table 4). 6-year overall survival (OS) was $85 \%$ in the elderly group as compared to $82 \%$ in the younger group ( $\mathrm{p}=0.840)$ (fig. 2$)$. If non-tumor-related deaths were
Table 1. Clinicopathological features of patients in the 2 groups

\begin{tabular}{|c|c|c|c|}
\hline & $\begin{array}{l}\text { Young group } \\
(\mathrm{n}=209), \\
\mathrm{n}(\%)\end{array}$ & $\begin{array}{l}\text { Elderly group } \\
(\mathrm{n}=213), \\
\mathrm{n}(\%)\end{array}$ & $\mathrm{p}$ \\
\hline Tumor stage & & & 0.018 \\
\hline $\mathrm{T} 1$ & $63(30.1)$ & $81(38.0)$ & \\
\hline $\mathrm{T} 2$ & $118(56.5)$ & $107(50.2)$ & \\
\hline $\mathrm{T} 3$ & $24(11.5)$ & $13(6.1)$ & \\
\hline $\mathrm{T} 4$ & $4(1.9)$ & $12(5.6)$ & \\
\hline Lymph node stage & & & 0.064 \\
\hline No & $100(47.8)$ & $128(60.1)$ & \\
\hline N1 & $60(28.7)$ & 46 (21.1) & \\
\hline N2 & $26(12.4)$ & $25(11.7)$ & \\
\hline N3 & $23(11.0)$ & $15(7.0)$ & \\
\hline Pathological stage & & & 0.037 \\
\hline I & $37(17.7)$ & $60(23.3)$ & \\
\hline II & $112(53.6)$ & $102(47.9)$ & \\
\hline III & $60(28.7)$ & 51(23.9) & \\
\hline $\mathrm{T} 1$ positive lymph nodes & & & 0.033 \\
\hline Yes & $27(42.9)$ & $21(25.9)$ & \\
\hline No & $36(57.1)$ & $60(74.1)$ & \\
\hline $\mathrm{T} 2$ positive lymph nodes & & & 0.519 \\
\hline Yes & $58(49.2)$ & $48(44.9)$ & \\
\hline No & $60(50.8)$ & $59(55.1)$ & \\
\hline T3 positive lymph nodes & & & 0.176 \\
\hline Yes & $21(87.5)$ & $9(69.2)$ & \\
\hline No & $3(12.5)$ & $4(30.8)$ & \\
\hline T4 positive lymph nodes & & & 0.551 \\
\hline Yes & $3(75.0)$ & $7(58.3)$ & \\
\hline No & $1(25.0)$ & $5(41.7)$ & \\
\hline Molecular classification & & & 0.018 \\
\hline Luminal A & $90(43.1)$ & $107(50.2)$ & \\
\hline Luminal B & 28 (13.4) & $24(11.3)$ & \\
\hline Her2 & $23(11.0)$ & $36(16.9)$ & \\
\hline Triple-negative & $58(27.8)$ & $33(15.5)$ & \\
\hline Unknown & $10(4.8)$ & $13(6.1)$ & \\
\hline Grade & & & 0.038 \\
\hline 1 & $43(20.6)$ & $52(24.4)$ & \\
\hline 2 & $72(34.4)$ & $91(42.7)$ & \\
\hline 3 & $94(45.0)$ & $70(32.9)$ & \\
\hline Histology & & & 0.49 \\
\hline Invasive carcinoma & $196(93.8)$ & $203(95.3)$ & \\
\hline Microinvasive carcinoma & $13(6.2)$ & $10(4.7)$ & \\
\hline
\end{tabular}

Table 2. Findings of breast imaging in the 2 groups

\begin{tabular}{llll}
\hline & $\begin{array}{l}\text { Young group } \\
(\mathrm{n}=85), \mathrm{n}(\%)\end{array}$ & $\begin{array}{l}\text { Elderly group } \\
(\mathrm{n}=110), \mathrm{n}(\%)\end{array}$ & $\mathrm{p}$ \\
\hline Ultrasonography findings & & & 0.723 \\
$\quad$ Positive & $82(96.5)$ & $105(95.5)$ & \\
$\quad$ Negative & $3(3.5)$ & $5(4.5)$ & 0.000 \\
Mammography findings & $45(52.9)$ & $104(94.5)$ & \\
$\quad$ Positive & $40(47.1)$ & $6(5.5)$ & \\
$\quad$ Negative & & & \\
\hline
\end{tabular}

Table 3. Therapeutic strategies in the 2 groups

\begin{tabular}{lccc}
\hline & $\begin{array}{l}\text { Young group } \\
(\mathrm{n}=209), \\
\mathrm{n}(\%)\end{array}$ & $\begin{array}{l}\text { Elderly group } \\
(\mathrm{n}=213), \\
\mathrm{n}(\%)\end{array}$ & $\mathrm{p}$ \\
\hline $\begin{array}{l}\text { Surgery } \\
\text { Radical mastectomy }\end{array}$ & $66(31.6)$ & $66(31.0)$ & 0.031 \\
$\quad \begin{array}{l}\text { Modify radical mastectomy } \\
130(62.2)\end{array}$ & $\begin{array}{c}144(67.6) \\
6(1.4)\end{array}$ & \\
$\quad \begin{array}{l}\text { Breast-conserving surgery } \\
\text { Chemotherapy }\end{array}$ & $13(6.2)$ & & 0.000 \\
$\quad$ Yes & $192(91.9)$ & $162(76.1)$ & \\
$\quad$ No & $17(8.1)$ & $51(23.9)$ & 0.027 \\
$\begin{array}{l}\text { Radiotherapy } \\
\text { Yes }\end{array}$ & $65(31.1)$ & $46(21.6)$ & \\
$\quad$ No & $144(68.9)$ & $167(78.4)$ & 0.45 \\
$\begin{array}{l}\text { Hormonal therapy } \\
\text { Yes }\end{array}$ & $121(57.9)$ & $131(61.5)$ & \\
$\quad$ No & $188(42.1)$ & $82(38.5)$ & \\
\hline
\end{tabular}


Table 4. Cox proportional hazards model for disease-free survival and overall survival

\begin{tabular}{|c|c|c|c|c|}
\hline & \multicolumn{2}{|l|}{ Disease progression } & \multicolumn{2}{|l|}{ Death } \\
\hline & $\operatorname{HR}(95 \% \mathrm{CI})$ & $\mathrm{p}$ & $\operatorname{HR}(95 \% \mathrm{CI})$ & $\mathrm{p}$ \\
\hline \multicolumn{5}{|l|}{ Age young vs. elderly } \\
\hline Univariate & $1.855(1.263-2.725)$ & 0.002 & $0.954(0.605-1.505)$ & 0.840 \\
\hline Multivariate & $1.557(1.035-2.3420)$ & 0.034 & $0.843(0.514-1.383)$ & 0.499 \\
\hline T stage & & 0.189 & & 0.099 \\
\hline $\mathrm{T} 2$ vs. $\mathrm{T} 1$ & $1.323(0.812-2.154)$ & 0.261 & $1.923(1.017-3.636)$ & 0.044 \\
\hline T3 vs. T1 & $1.210(0.603-2.431)$ & 0.592 & $1.255(0.468-3.3260)$ & 0.652 \\
\hline Lymph node status & & 0.000 & & 0.000 \\
\hline N1 vs. N0 & $2.046(1.208-3.466)$ & 0.008 & $1.268(0.815-3.253)$ & 0.167 \\
\hline N2 vs. N0 & $4.437(2.553-7.711)$ & 0.000 & $3.465(1.720-6.978)$ & 0.001 \\
\hline N3 vs. N0 & $6.322(3.476-11.497)$ & 0.000 & $7.259(3.682-14.310)$ & 0.000 \\
\hline ER present vs. absent & $0.655(0.378-1.134)$ & 0.131 & $0.838(0.438-1.605)$ & 0.594 \\
\hline PgR present vs. absent & $1.104(0.643-1.895)$ & 0.720 & $0.654(0.347-1.231)$ & 0.188 \\
\hline Her2 present vs. absent & $1.584(1.057-2.373)$ & 0.026 & $1.219(0.725-2.049)$ & 0.455 \\
\hline Grade 3 vs. $1 / 2$ & $1.657(1.113-2.465)$ & 0.013 & $1.456(0.899-2.357)$ & 0.126 \\
\hline Chemotherapy yes vs. no & $0.842(0.414-1.712)$ & 0.635 & $0.564(0.253-1.255)$ & 0.161 \\
\hline
\end{tabular}

$\mathrm{HR}=$ Hazard ratio; $95 \% \mathrm{CI}=95 \%$ confidence interval; $\mathrm{ER}=$ estrogen receptor; $\mathrm{PgR}=$ progesterone receptor.

not included, there also was no significant difference between the 2 groups in terms of tumor-specific death rate $(p=0.859)$. On univariate and multivariate analysis, young age was not an independent prognostic factor for decreased OS. Positive lymph node status was the only prognostic factor associated with decreased OS in our study (trend $\mathrm{p}<0.001$ ).

In the subgroup analysis based on pathological stages, the 6-year DFS for stages I, II and III was 85, 76 and $41 \%$ in the very young group, and 93, 84 and $54 \%$ in the elderly group, respectively. Only the difference in DFS for stage II achieved statistical significance $(p=0.033)$, and the DFS of the elderly group was better than that of the very young group. The 6-year OS for stages I, II and III was 94,88 and $64 \%$ in the very young group, and 95, 82 and $77 \%$ in the elderly group, respectively, without significant differences among all stages ( $\mathrm{p}=0.500,0.125$ and 0.402 , respectively). In addition, in the subgroup analysis based on molecular subtypes, 6-year DFS for subtype Luminal A in the very young group was poorer than in the elderly group (67 vs. $87 \%$; p < 0.001). There was no significant difference between DFS for other subtypes ( $p=0.463,0.704$ and 0.225 , respectively), and no significant differences occurred for OS with any subtype.

\section{Discussion}

Breast cancer in very young women is thought to be a special subgroup of breast cancer. Although its definition is controversial, most studies define this subgroup as age of onset less than 35 years $[3,5,12]$. Generally, this type of breast cancer is thought to be less well differentiated and to have low hormone receptor expression and more vascular invasion, resulting in more aggressive biological behavior [13-15]. We selected patients aged older than 60 years as our control group in order to explore the features of breast cancer in very young women, since age 60 is defined as the standard of menopause by the National Comprehensive Cancer Network. Anders et al. [16] even selected patients aged older than 65 years as control group to explore the potential biologic basis of younger breast cancer patients, and postmenopausal status is well documented as an independent good prognostic factor for breast cancer [17]. In the present study, we analyzed the relationship between tumor size and lymph node involvement, and found that young patients with stage T1 tumors had more lymph node involvement. This may be explained by the more aggressive biological behavior occurring in younger patients. Furthermore, our study revealed that $11.1 \%$ of registered operable breast cancer patients in China were very young. In Western countries, however, only about $2-3 \%$ of patients with breast cancer are very young [6]. This may be due to the earlier onset trend of breast cancer in Chinese women reported previously [10]. Thus, the study of breast cancer in very young women is even more important in China.

In the present study, tumor size was significantly different between the 2 groups, with less T1 tumors ( 30.1 vs. $38 \%$ ) but more $\mathrm{T} 2$ and $\mathrm{T} 3$ tumors in the very young group. This trend of larger tumor sizes at diagnosis can be explained by the more rapid proliferation features of breast cancer in young patients compared to elderly patients $[3,18]$. On the other hand, delayed diagnosis is probably partly due to the fact that the breast tissue of younger women is denser and therefore it is more difficult to detect breast cancer by physical examination and mammography [19-21]. Furthermore, because of the lower incidence of breast cancer diagnosed at a young age, both women and physicians might perform breast examinations less often and dismiss putative abnormalities [20]. In our study, $47.1 \%$ of tumors were not detected by mammography in the very young group as compared to $5.5 \%$ in elderly group $(\mathrm{p}<0.001)$, whereas the tumor detection rate of ultrasonography was similar in the 2 groups $(96.5$ vs. $95.5 \%, p=0.723)$. Further examination by ultrasound may improve the detection rate in young patients. 
In the present study, significant differences were seen in the molecular subtype analysis between the 2 groups. Less Luminal A tumors were observed in the very young group than in the elderly group ( 43.1 vs. $50.2 \%$ ), while there were more triple-negative tumors in the very young group (27.8 vs. $15.5 \%$ ). The 6-year DFS for subtype Luminal A in the very young group was poorer than in the elderly group (67 vs. 87\%; $\mathrm{p}<0.001)$. When Cancello et al. [5] performed their analysis using age 35 as cut-off value for age of onset, the proportions were 9.2 and $21.2 \%$ for subtype Luminal A and 16.2 and $7.5 \%$ for subtype triple-negative, in the younger and the older group, respectively. This is similar to our result, but the difference in DFS mainly existed in the Luminal B groups. The study by Carey et al. [11] also revealed more tumors of the Luminal A and B subtype in postmenopausal patients, and Bauer et al. [22] also found more triple-negative subtypes in patients younger than 40 years. Although young age is defined differently in these studies, it is certain that there is a lower proportion of hormone-positive tumors in younger patients and a different molecular subtype distribution among younger and older patients. Whether personalized therapy should be delivered to younger and elderly patients according to their different molecular subtypes merits further study.

Whether age of onset is associated with prognosis and can be an independent factor of prognosis in breast cancer remains controversial so far. Many studies revealed obvious survival differences between young and elderly breast cancer patients $[2,5]$. Subgroup analysis in some studies revealed survival differences in patients with hormone receptor-positive tumors, but no differences in those with hormone receptornegative tumors $[12,23]$. However, some studies concluded that young age had no impact on $[6,8]$ or even improved the prognosis [4, 9]. The inconsistent results from different studies can be explained by the following factors: relatively smaller sample sizes of very young patients included; inconsistent age ranges for control groups in different studies although the cutoff value for age at diagnosis was 35 years in most studies; changes in therapy strategies during study inclusion due to long time intervals for inclusion; possible heterogeneities among different races and different treatment regimens. In the present study, the time interval for inclusion was 5 years, breast cancer patients registered in our center were treated consistently according to our treatment guideline during this period. Although less patients received chemotherapy in the elderly group due to unwillingness or comorbidities, 6-year DFS in the very young group was poorer than in the elderly group (66 vs. $80 \%$; $=0.001$ ). Multivariate analyses found that young age was an independent prognostic factor for decreased DFS. This difference in DFS can be explained by the more aggressive features of breast cancers in very young women, while the similar OS may be attributed to differences in chemotherapy between the 2 groups $(\mathrm{p}<0.001)$. Furthermore, survival could be improved in the very young group by intensive comprehensive therapy after relapse. Subgroup analysis revealed that the difference in DFS mainly existed in patients of stage II, and most patients of stage II had T2 or N1 disease. Whether radiotherapy should be delivered to patients in stage II to improve locoregional control merits further study.

Overall, the proportion of very young age-onset breast cancer is high in China, and it is more difficult to detect by physical examination and mammography. To avoid delayed diagnosis, clinicians should pay more attention to breast abnormalities seen in very young patients. Compared with elderly women, breast cancers in very young women were characterized by larger tumor size, less hormone-responsiveness, more aggressive molecular subtypes, and poorer DFS. Development of tailored treatment for this subgroup of breast cancer is necessary.

\section{Acknowledgements}

Support for this work was provided by the Foundation of the Ministry of Science and Technology of Guangdong Province (2011B080701052).

\section{Disclosure Statement}

The authors declare no conflicts of interest.

\section{References}

$>_{1}$ Gennari R, Curigliano G, Rotmensz N, Robertson C, Colleoni M, Zurrida S, Nole F, de Braud F, Orlando L, Leonardi MC, Galimberti V, Intra $\mathrm{M}$, Veronesi $\mathrm{P}$, Renne $\mathrm{G}$, Cinieri S, Audisio RA, Luini A, Orecchia R, Viale G Goldhirsch A: Breast carcinoma in elderly women: features of disease presentation, choice of local and systemic treatments compared with younger postmenopasual patients. Cancer 2004:101:1302-1310.

2 Han W, Kim SW, Park IA, Kang D, Kim SW, Youn YK, Oh SK, Choe KJ, Noh DY: Young age: an independent risk factor for disease-free survival in women with operable breast cancer. BMC Cancer 2004; 4:82.
3 Colleoni M, Rotmensz N, Robertson C, Orlando L, Viale G, Renne G, Luini A, Veronesi P, Intra M, Orecchia R, Catalano G, Galimberti V, Nole F, Martinelli G, Goldhirsch A: Very young women ( $<35$ years) with operable breast cancer: features of disease at presentation. Ann Oncol 2002;13:273279.

4 Chia KS, Du WB, Sankaranarayanan R, Sankila R, Wang H, Lee J, Seow A, Lee HP: Do younger female breast cancer patients have a poorer prognosis? Results from a population-based survival analysis. Int J Cancer 2004;108:761-765.
Cancello G, Maisonneuve P, Rotmensz N,
Viale G, Mastropasqua MG, Pruneri G,
Veronesi P, Torrisi R, Montagna E, Luini A,
Intra M, Gentilini O, Ghisini R, Goldhirsch A,
Colleoni M: Prognosis and adjuvant treatment
effects in selected breast cancer subtypes of very
young women (<35 years) with operable breast
cancer. Ann Oncol 2010;21:1974-1981.
6 Rapiti E, Fioretta G, Verkooijen HM, Vlastos G,
Schafer P, Sappino AP, Kurtz J, Neyroud-Caspar
I, Bouchardy C: Survival of young and older breast
cancer patients in Geneva from 1990 to 2001. Eur J Cancer 2005;41:1446-1452. 
7 Barchielli A, Balzi D: Age at diagnosis, extent of disease and breast cancer survival: a population-based study in Florence, Italy. Tumori 2000;86:119-123.

8 Kroman N, Jensen MB, Wohlfahrt J, Mouridsen HT, Andersen PK, Melbye M: Factors influencing the effect of age on prognosis in breast cancer: population based study. BMJ 2000;320:474-478.

9 La Rosa F, Patavino VM, Epifani AC, Petrinelli AM, Minelli L, Mastrandrea V: Ten-year survival and age at diagnosis of women with breast cancer from a population-based study in Umbria, Italy. Tumori 1996;82:441-443.

10 Yang MT, Rong TH, Huang ZF, Zeng CG, Long H, Fu JH, Lin P, Wang X, Wang SY, Wang X, Tang J: (Clinical analysis of resectable breast cancer: a report of 6263 cases). Ai Zheng 2005;24:327-331.

11 Carey LA, Perou CM, Livasy CA, Dressler LG,Cowan D, Conway K, Karaca G, Troester MA, Tse CK, Edmiston S, Deming SL, Geradts J, Cheang MC, Nielsen TO, Moorman PG, Earp HS, Millikan RC: Race, breast cancer subtypes, and survival in the Carolina Breast Cancer Study. JAMA 2006;295:2492-2502.

12 Han W, Kang SY: Relationship between age at diagnosis and outcome of premenopausal breast cancer: age less than 35 years is a reasonable cut-off for defining young age-onset breast cancer. Breast Cancer Res Treat 2010;119:193200.

13 Walker RA, Lees E, Webb MB, Dearing SJ: Breast carcinomas occurring in young women (<35 years) are different. Br J Cancer 1996;74:1796-1800.

14 Chung M, Chang HR, Bland KI, Wanebo HJ: Younger women with breast carcinoma have a poorer prognosis than older women. Cancer 1996;77:97-103.

15 Winchester DP, Osteen RT, Menck HR: The national cancer data base report on breast carcinoma characteristics and outcome in relation to age. Cancer 1996;78:1838-1843.

16 Anders CK, Hsu DS, Broadwater G, Acharya CR, Foekens JA, Zhang Y, Wang Y, Marcom PK, Marks JR, Febbo PG, Nevins JR, Potti A, Blackwell KL: Young age at diagnosis correlates with worse prognosis and defines a subset of breast cancers with shared patterns of gene expression. J Clin Oncol 2008;26:3324-3330.

17 Grady D: Clinical practice. Management of menopausal symptoms. N Engl J Med 2006;355:2338-2347.

18 Maggard MA, O'Connell JB, Lane KE, Liu JH, Etzioni DA, Ko CY: Do young breast cancer patients have worse outcomes? J Surg Res 2003; 113:109-113.

19 Althuis MD, Brogan DD, Coates RJ, Daling JR, Gammon MD, Malone KE, Schoenberg JB, Brinton LA: Breast cancers among very young premenopausal women (united states). Cancer Causes Control 2003;14:151-160.

20 Montella M, Crispo A, D’Aiuto G, De Marco M, de Bellis G, Fabbrocini G, Pizzorusso M, Tamburini M, Silvestra P: Determinant factors for diagnostic delay in operable breast cancer patients. Eur J Cancer Prev 2001;10:53-59.

21 Schreer I: Dense breast tissue as an important risk factor for breast cancer and implications for early detection. Breast Care (Basel) 2009;4:89-92.

-22 Bauer KR, Brown M, Cress RD, Parise CA, Caggiano V: Descriptive analysis of estrogen receptor (ER)-negative, progesterone receptor (PR)negative, and Her2-negative invasive breast cancer, the so-called triple-negative phenotype: a population-based study from the California Cancer Registry. Cancer 2007;109:1721-1728.

-23 Colleoni M, Rotmensz N, Peruzzotti G, Maisonneuve P, Orlando L, Ghisini R, Viale G, Pruneri G, Veronesi P, Luini A, Intra M, Cardillo A, Torrisi R, Rocca A, Goldhirsch A: Role of endocrine responsiveness and adjuvant therapy in very young women (below 35 years) with operable breast cancer and node negative disease. Ann Oncol 2006;17:1497-1503. 